\title{
L'araire en Inde du Sud
}

Aspects techniques, sociaux et linguistiques

\section{Yoshio Abé}

\section{(2) OpenEdition}

\section{Journals}

Édition électronique

URL : https://journals.openedition.org/tc/765

DOI : $10.4000 /$ tc. 765

ISSN : 1952-420X

Éditeur

Éditions de l'EHESS

\section{Édition imprimée}

Date de publication : 1 octobre 1990

ISSN : 0248-6016

\section{Référence électronique}

Yoshio Abé, "L'araire en Inde du Sud », Techniques \& Culture [En ligne], 14 | 1990, mis en ligne le 16 janvier 2006, consulté le 29 septembre 2022. URL : http://journals.openedition.org/tc/765; DOI : https://doi.org/10.4000/tc.765

Ce document a été généré automatiquement le 29 septembre 2022.

Tous droits réservés 


\section{L'araire en Inde du Sud}

Aspects techniques, sociaux et linguistiques

\section{Yoshio Abé}

